\title{
The Analysis of the Influence of Credit Service Quality of Credit Customer Satisfaction and Its Impact on Loyalty
}

(Case Study of Credit Customers at PT. Bank Mandiri (Persero) Tbk. Sentra in Bandung)

\author{
Astrin Kusumawardani ${ }^{1, *}$ Yoyo Sudaryo ${ }^{2,}$ M. Iqbal Alamsyah ${ }^{3,}$ Tjipto Sajekti ${ }^{4}$
}

${ }^{1}$ STIE INABA Business School

${ }^{2}$ STIE INABA Business School

${ }^{3}$ STIE INABA Business School

${ }^{4}$ STIE INABA Business School

*Corresponding author. Email: astrin.kusumawardani@inaba.ac.id

\begin{abstract}
Banks are the heart and pulse of the trade and economic development of a country. Therefore, banks become one of the financial institutions that have an essential role in driving a country's economy, including Indonesia. The management of government banks has not comprehensively improved the quality of service, satisfaction, and loyalty of credit customers. This is indicated by the continued dissatisfaction of bank credit customers with banks' services that cover the fulfillment of the needs and interests of credit customers, especially in credit applications. Furthermore, the management of PT. Bank Mandiri (Persero) Tbk. has not been fully able to make credit customer satisfaction in the banking business activities it manages. The research method used in this research is descriptive and verification research. The population of this study is the credit customers of PT. Bank Mandiri (Persero) Tbk. The sampling technique employed proportional stratified random sampling that studied as many as 61 people with smooth credit and 79 bad credit customers. The Likert Scale, a research scale used to measure attitudes and opinions, was treated as an instrument used by researchers. The results showed that the quality of credit services PT. Bank Mandiri (Persero) Tbk. as a whole has been implemented well. Tangibility had been implemented well, officers were reliable and responsive, assurance can be trusted, and officers expressed empathy. Credit customers are satisfied with the services provided, the loyalty of credit customers of PT. Bank Mandiri (Persero) Tbk. has achieved well. There is an influence of lending service quality on customer loyalty at PT. Bank Mandiri (Persero) Tbk. There is also an influence between the quality of lending services on credit customer satisfaction implications on the credit loyalty of PT. Bank Mandiri (Persero) Tbk partially and simultaneously.
\end{abstract}

Keywords: Quality of Service, Providing Credit, Customer Satisfaction.

\section{INTRODUCTION}

Banks become one of the financial institutions that have an essential role in driving a country's economy, including Indonesia. The public as consumers or the banking industry's target market has various considerations in choosing the banking service business that they will use.

These factors are the basis for public consideration to choose banking services, both directly and indirectly, which can form loyalty in the community towards the Bank, which is used as a choice they trust. In its development, PT. Bank Mandiri (Persero) Tbk developed innovations to attract customers.

Customer satisfaction is the main thing that should not be ignored for someone engaged in banking services. Customer satisfaction is an important aspect to maintain banking's image in the broader community, so quality service for customers needs to be improved. Improving the quality of service to customers is essential in efforts 
to increase customer satisfaction. This is very important because given the very large role of customers in the influence of income directly or indirectly to support its existence.

Quality of Service PT. Bank Mandiri (Persero) Tbk. must be able to provide the best for its customers. The customer is an essential asset for PT. Bank Mandiri (Persero) Tbk. both saving and credit customers. This is because customers are the primary source of third-party fund collection by PT. Bank Mandiri (Persero) Tbk. PT. Bank Mandiri (Persero) Tbk can use these third-party funds to extend credit to the business world or the public who need it.

\subsection{Quality}

Quality is a dynamic condition that affects products, services, people, processes, and environments that meet or exceed expectations [1]. Thus, the definition of service quality can be interpreted as an effort to meet the needs and desires of consumers and the accuracy of delivery in balancing consumer expectations [2]. Reference [3] states that quality is a measure to assess that an item or service has a use-value as desired or, in other words, a product or service is considered to have quality if it functions or has a use-value as desired. From some of these definitions, it can be concluded that quality is an interrelated element of quality that can affect performance in meeting customer expectations.

\subsection{Quality of service}

Customer satisfaction is: "As a quantitative index, customer satisfaction describes the difference between expectation and perceived quality, and measures the degree of satisfaction". Customer satisfaction as a quantitative index, customer satisfaction describes the difference between expectations and perceived quality and measures the degree of satisfaction [4].

Reference [5], quoted from the book Marketing Management said that Consumer Satisfaction is a feeling of pleasure or disappointment someone who appears after comparing the performance (results) of products thought to the expected performance.

Reference [6], "Satisfaction is a person's feelings of pleasure or disappointment that results from comparing a product's perceived performance or outcome to expectations. If the performance falls short of expectations, the outcome is dissatisfied. If it matches expectations, the customer is satisfied or delighted. "Which means satisfaction is someone's feeling of satisfaction or disappointment resulting from a comparison of product performance or results with expectations. If the performance is less than expectations, the customer will be disappointed, and if under expectations, the consumer will feel satisfied.
Reference [7], satisfaction comes from the Latin "Satis" which means pretty good, adequate, and "Facio" which means to do or make.

\subsection{Loyalty}

Reference [8] argues that the occurrence of brand loyalty to consumers is caused by the influence of satisfaction and dissatisfaction with the brand that accumulates continuously and the perception of product quality.

Customer loyalty, according [9], is customer attachment to a brand, shop, manufacturer, service provider, or other entity based on a favorable attitude and good response, such as repurchase. Based on these definitions, it can be concluded that there are behavioral and attitude elements in customer loyalty.

Refenrence [10], Consumer loyalty is the loyalty of consumers to shop at specific locations. Loyalty is not formed quickly but through a learning process and based on the results of the experience of consumers themselves from purchases over time. If what is obtained is in line with expectations, the buying process continues to repeat. This can be said that loyalty has arisen.

\section{METHODS}

The scientific method means research activities that are based on scientific characteristics. Reference [11] states the following scientific characteristics, namely rational, empirical, and systematic. In connection with the problem raised in this study, the authors used a quantitative research design in a descriptive study and verification study with a path analysis technique approach. Path analysis is used to analyze causal relationships, to determine the direct effect and indirect effect of a cause variable on the effect variable [12].

Distribution of questionnaires with Google Forms, according [13] "Google Forms or commonly referred to as Google Forms is one of Google's features that aims to make it easier for users to make a survey/form via the internet".

\section{RESULTS AND DISCUSSION}

\subsection{Quality of bank loan service}

Quality is a dynamic condition that affects products, services, people, processes, and environments that meet or exceed expectations [1]. So the definition of service quality can be interpreted as an effort to meet customers' needs and desires as well as the accuracy of delivery in balancing customer expectations [2].

Descriptive analysis results from research data at PT. Bank Mandiri (Persero) Tbk. According to tangible aspects (direct evidence), the quality of credit services 
has good criteria with an actual percentage score of $66.03 \%$. The thing that was rated the most by PT. Bank Mandiri (Persero) Tbk. customers were related to the appearance of customer service $(69.27 \%)$. Of the three tangible indicators, the office's overall physical appearance $(64.31 \%)$ has the most recent rating assessed by PT. Bank Mandiri (Persero) Tbk. customers.

Furthermore, related to the reliability factor (reliability), the results show that the promised service following the wishes of credit customers $(66.41 \%)$ is the largest percentage compared to other items. In comparison, credit officers provide clarity of information $(62.40 \%)$, which is the lowest percentage for the reliability factor.

From the responsiveness (responsiveness) aspect, the results show complaints from credit customers are dealt with quickly by PT. Bank Mandiri (Persero) Tbk. loan officers $(62.02 \%)$, while in the face of problems, loan officers are judged quite quickly by credit customers $(56.49 \%)$

Concerning the assurance aspect (guarantee), credit customers feel that the credit requirements at PT. Bank Mandiri (Persero) Tbk. are easy $(67.18 \%)$ at the first rank, while the knowledge of loan officers about bank loans $(61.26 \%)$ is at the last rating of this assurance aspect.

Finally, from the empathy aspect (empathy), the leading indicators chosen by respondents regarding credit officers pay attention to the needs of credit customers $(67.18 \%)$, while the last position is the indicator of credit officers caring for credit customers $(58.78 \%)$.

Based on the results of the analysis of the proportion test using the Z-test, it was concluded that the quality of lending services at PT. Bank Mandiri (Persero) Tbk. has been well implemented. With the magnitude of the contribution of respondents' answers to the variable quality of credit services by $63.87 \%$ included in the high acquisition category $(60 \%-80 \%)$. Indicators that cause the quality of credit services are in good condition are tangibles, reliability, assurance, and empathy.

\subsection{Credit customer satisfaction}

Reference [5] said that Consumer Satisfaction is a feeling of pleasure or disappointment someone who appears after comparing the performance (results) of products thought to with the expected performance.

Reference [6], "Satisfaction is a person's feelings of pleasure or disappointment that results from comparing a product's perceived performance or outcome to expectations. If the performance falls short of expectations, the outcome is dissatisfied. If it matches expectations, the customer is satisfied or delighted. "Which means satisfaction is someone's feeling of satisfaction or disappointment resulting from a comparison of product performance or results with expectations. If the performance is less than expectations, the customer will be disappointed, and if under expectations, the consumer will feel satisfied. Descriptive analysis of the results of research data at PT. Bank Mandiri (Persero) Tbk. shows that the level of customer satisfaction expected (expectation) is on the criteria of satisfaction with the actual percentage score of $64.22 \%$. Meanwhile, related to the perceived satisfaction factor (perception), being on the criteria of being satisfied with the actual score percentage of $65.65 \%$.

Based on the results of the analysis of the proportion test using the Z-test, it can be concluded that credit customers' satisfaction at PT. Bank Mandiri (Persero) Tbk. has been well achieved. With the large contribution of respondents' answers to the variable credit, customer satisfaction of $64.93 \%$ included in the high acquisition category $(60 \%-80 \%)$. Indicators that cause customer satisfaction are met, especially indicators of satisfaction by PT. Bank Mandiri (Persero) Tbk. credit customers.

\subsection{Credit customer loyalty at bank}

Customer loyalty can be reflected in the customer's habit of consistently buying products or services. Customers who already have loyalty to a product or service will usually no longer consider buying a product for services other than the product or service of interest. However, if the customer does not get a satisfying product or service, the customer will likely continue to look for products or services that fit their criteria. According to [14], loyalty can be defined based on the buying behavior of someone accustomed to buying. These habits are formed through frequent purchases and interactions over a certain period.

The descriptive analysis of research data at PT. Bank Mandiri (Persero) Tbk shows that referrals are infrequent criteria with an actual percentage score of $65.33 \%$. This referral's essential thing is related to credit customers' frequency in increasing the amount of credit $(68.89 \%)$.

Furthermore, related to the buy with line product factor $(64.03 \%)$, the results show that the highest percentage of credit customers frequently conduct transactions through Giro $(67.86 \%)$, while the indicator is often the credit customers make transactions through Deposits $(61.45 \%)$ is in the final position in the buy with line product factor at PT. Bank Mandiri (Persero) Tbk.

In the reference factor, the results show that the one who has the largest percentage of frequent credit customers recommends banking products or services to others $(65.46 \%)$.

Finally, for the sub-variable immunity $(64.89 \%)$, the highest indicator of the acquisition of the percentage is that the rarity of credit customers shows interest in other banking services $(65.65 \%)$. 
Based on the results of the analysis of the proportion test using the Z-test, it was concluded that credit customers were loyal to PT. Bank Mandiri (Persero) Tbk With the magnitude of the contribution of respondents' answers to the variable credit customer loyalty of $64.75 \%$ included in the high acquisition category $(60 \%-80 \%)$. Indicators that cause customer loyalty are met on each factor, especially the indicator of frequent credit customers to add the amount of credit to PT. Bank Mandiri (Persero) Tbk.

\subsection{The effect of quality of credit provion service on customer credit satisfaction}

There is a significant influence on the quality of credit services on credit customer satisfaction at PT. Bank Mandiri (Persero) Tbk as indicated by the statistical value of the t-test of 8.337 (significance $=0.000<5 \%$ ) in absolute smaller critical z 1.96 . The path coefficient is positive at 0.593 , which indicates that if other variables are considered constant, each increase in one unit of credit service quality will result in increased credit customer satisfaction by 0.593 units. The magnitude of the influence of credit services' quality on credit customer satisfaction by $35.20 \%$, while the remaining $64.80 \%$ is influenced by other factors outside the research variable.

Empirically this shows that the quality of lending services affects the satisfaction of credit customers. If the quality of credit services is implemented well, it will cause customers to be satisfied. There is an influence of service quality on PT. Bank Mandiri (Persero) Tbk credit customer satisfaction.

\subsection{The effect of quality of credit provision service on customer loyalty}

There is a significant influence on the quality of credit services on credit customer loyalty at PT. Bank Mandiri (Persero) Tbk as indicated by the statistical value of the t-test of 4.843 (significance $=0.000<5 \%$ ) in absolute smaller $\mathrm{z}$ critical 1.96. The path coefficient is positive with a value of 0.324 , which indicates that if other variables are considered constant, each increase in one unit of credit service quality will increase customer credit loyalty by 0.324 units. The magnitude of the influence of credit services' quality on credit customer loyalty is $21.20 \%$, while the remaining $78.80 \%$ is influenced by other factors outside the research variable.

Empirically this shows that the quality of credit service affects the loyalty of credit customers. If the quality of credit services is implemented well, it will cause customers to become loyal. In the industrial world, customer loyalty is a measure of success in a service business. Customers will feel much more satisfied when they can meet customer needs far beyond what is expected. It depends on the quality of service from the staff in providing services.

\subsection{Effect of customer satisfaction on purchasing desicions}

The results of this study indicate that there is a significant influence of customer credit satisfaction on customer loyalty at PT. Bank Mandiri (Persero) Tbk, which is indicated by the statistical value of the t-test of 8.229 (significance $=0,000<5 \%$ ) in absolute smaller $\mathrm{z}$ critical 1.96. The path coefficient is positive at 0.555 , which indicates that if other variables are considered constant, each increase in one unit of credit customer satisfaction will increase credit customer loyalty by 0.555 units. The magnitude of the influence of credit customer satisfaction on credit customer loyalty by $41.50 \%$, while the remaining $58.50 \%$ is influenced by other factors outside the research variable.

Empirically this shows that credit customer satisfaction affects credit customer loyalty. If the customer feels satisfied, it will result in the customer being loyal to this company. That the research referred to is motivated by the phenomenon of competition in the banking industry in order to obtain customer loyalty. Many banks, especially in the Pemalang area, make PT. Bank Mandiri (Persero) Tbk the Pemalang branch need to maintain and improve new strategies to keep their customers loyal and even increase their number of customers.

\subsection{The effect of credit service quality on credit customer satisfaction and its impact on credit customer loyalty}

There is a significant influence on the quality of credit services on credit customer loyalty through credit customer satisfaction at PT. Bank Mandiri (Persero) Tbk. which is indicated by the statistical value of the $\mathrm{F}$ test count of 107,960 (significance $=0,000<5 \%$ ) in greater critical F 3,066. The determinant coefficient is 0.626 or $62.6 \%$, so the magnitude of the effect of credit services' quality on credit customer loyalty through credit customer satisfaction is $62.6 \%$, while the remaining $37.4 \%$ is influenced by other factors outside the research variable.

Empirically, this shows that the quality of credit service affects credit customers' satisfaction and impacts the loyalty of credit customers. If the quality of credit service is implemented well, credit customers are satisfied that they will be loyal to the company.

\section{CONCLUSIONS}

1. The results showed that the quality of credit services PT. Bank Mandiri (Persero) Tbk. as a whole has been implemented well. Tangibility had been implemented well, officers were reliable and responsive, assurance can be trusted, and officers expressed empathy. 
2. Credit customers are satisfied with the services provided, the loyalty of credit customers of PT. Bank Mandiri (Persero) Tbk.

3. Thas achieved well. There is an influence of lending service quality on customer loyalty at PT. Bank Mandiri (Persero) Tbk.

4. There is also an influence between the quality of lending services on credit customer satisfaction implications on the credit loyalty of PT. Bank Mandiri (Persero) Tbk partially and simultaneously.

5. There is an influence on the quality of lending services on credit customers' satisfaction at PT. Bank Mandiri (Persero) Tbk.

6. There is an influence on the quality of lending services on credit customers' loyalty at PT. Bank Mandiri (Persero) Tbk.

7. There is an influence of credit customer satisfaction on credit customer loyalty at PT. Bank Mandiri (Persero) Tbk There is an influence on the quality of credit services on credit customer satisfaction, which has implications for PT. Bank Mandiri (Persero) Tbk credit customers' loyalty both partially and simultaneously.

\section{ACKNOWLEDGMENT}

This research was supported by the Director of the Indonesian Institute of Economic Science Building (STIE INABA), Bandung. We thank our colleagues in the Study Program of Accounting and Management of the Institute of Economist Science in Indonesia Development (STIE INABA) who has helped in this research. This research can be done well. Hopefully, this research can be useful in developing education.

\section{REFERENCES}

[1] F. Tjiptono, Service management mewujudkan layanan prim, 2 Ed. Yogyakarta: Andi, 2011.
[2] F. Tjiptono, Strategi pemasaran, 2 Ed. Yogyakarta: Andi, 2007.

[3] S. Danang, Manjemen sumber daya manusia. Jakarta: PT. Buku Seru, 2012.

[4] K. Jian, Z. Xin, and Z. Zhao-hong, "The relationship of customer complaints, satisfaction and loyalty : Evidence from China's mobile phone industry," china-USA Bus. Rev., 2009.

[5] P. Kotler, and K.L, Keller, Manajemen pemasaran, Jilid 1, 12 Ed. Jakarta: PT. Indeks, 2007.

[6] P. Kotler, and K.L, Keller, Manajemen pemasaran, Jilid 1, 12 Ed. Jakarta: Erlangga, 2012.

[7] F. Tjiptono, Pemasaran jasa: prinsip, penerapan, dan penelitia. Yogyakarta: Andi Offset, 2014.

[8] H. Ali, Marketing, Yogyakarta: Media Utama, 2008.

[9] A.W. Tunggal, Dasar - dasar customer relationship management (CRM). Jakarta: Haryindo, 2008.

[10] C.W. Utami, Managemen ritel (strategi dan implementasi ritel modern). Jakarta: Salemba Empat, 2006.

[11] Sugiyono, Metode penelitian pendidikan pendekatan kuantitatif, kualitatif, dan R\&D. Bandung: Alfabeta, 2010.

[12] F.N. Karlinger, Asas-asas penelitian behavioral, 3 Ed. Yogyakarta: Gajah Mada University Press, 2003.

[13] Y. Sudaryo, N.A. Sofiati, A. medidjati, and A. Hadiana, Metode penelitian survei online dengan google form, 1 Ed. Yogyakarta : Andi, 2019.

[14] J. Griffin, Constomer loyalty: menumbuhkan \& mempertahankan kesetiaan pelanggan. Jakarta: Erlangga, 2014. 